\title{
ACCUMULATION OF SOME HEAVY METALS AND HISTOLOGICAL ASPECTS OF BODY TISSUES OF GROWING FRIESIAN CALVES FED POULTRY LITTER AND CORN SILAGE
}

\author{
H.M.A. Gaafar ${ }^{1}$, R.M. Abou-Aiana ${ }^{1}$, G.H.A. Ghanem ${ }^{1}$ and Mona A. Ali $^{2}$ \\ 1- Animal Production Research Institute, Agricultural Research Center, Dokki, \\ Giza, 2- Faculty of Veterinary, Kafr El-Sheikh, Tanta University
}

\section{SUMMARY}

Eighteen male growing Friesian calves averaging $187 \pm 2.50 \mathrm{~kg}$ body weight and $9 \pm 0.19$ months of age were used to study the effect of feeding rations containing different levels of poultry litter and corn silage on some heavy metals accumulation and histological aspects of body tissues. Calves were divided into three similar groups (6 in each) and were assigned randomly to the three experimental rations as follows:

$\boldsymbol{R} 1$ (control): $65 \%$ concentrate feed mixture $+15 \%$ berseem hay $+20 \%$ rice straw.

R2: $12.5 \%$ poultry litter $+12.5 \%$ corn grains $+75 \%$ corn silage.

R3: $25 \%$ poultry litter $+25 \%$ corn grains $+50 \%$ corn silage.

The contents of copper (Cu), cadmium (Cd) and lead $(\mathrm{Pb})$ were higher in poultry litter compared to the other tested feedstuffs. The concentrations of $\mathrm{Cu}, \mathrm{Cd}$ and $\mathrm{Pb}$ in experimental rations and intake by growing calves increased with increasing the level of poultry litter and decreasing the level of corn silage.

The concentrations of $\mathrm{Cu}, \mathrm{Cd}$ and $\mathrm{Pb}$ in blood and seminal plasma, liver, kidneys, testes and muscles of growing Friesian calves significantly $(P<0.05)$ increased when the level of poultry litter was increased and the level of corn silage was decreased. The concentrations of $\mathrm{Cu}, \mathrm{Cd}$ and $\mathrm{Pb}$ in blood and seminal plasma, liver, kidneys, testes and muscles of growing Friesian calves fed R3 which contained 25\% poultry litter were higher than the normal levels.

Friesian calves fed R1 and R2 showed normal histological structure of body tissues. However, calves fed R3 showed severely damaged hepatocytes, more vacuolated and enlarged hepatocytes, lymphocytic infiltration between hepatocytes and necrotic area of hepatocytes of liver. Glomeruli lost their architecture and lumen of convoluted tubule besides the lymphocytic infiltration of kidneys. Degenerations and necrosis of the testes were observed while the semineferous tubles and their lumens were free from spermatozoa.

It could be concluded that using poultry litter in the ration of growing calves fed corn silage at the level of 25\% of DM basis led to an increase in the concentration of heavy metals in blood and seminal plasma and accumulation in body tissues causing abnormal histological aspects. So, poultry litter should not exceed $12.5 \%$ on DM basis of the ration.

Issued by The Egyptian Society of Animal Production 
Keywords: Friesian calves, poultry litter, corn silage, heavy metal, blood and seminal plasma, body tissues and histological aspects.

\section{INTRODUCTION}

Copper compounds, particularly sulfate, have been widely used in purifing the houses of poultry and occasionally accumulated in poultry litter (Westing et al., 1985). Of all the minerals, copper is the most likely to become toxic when over supplemented. Copper toxicities can occur in cattle that consume excessive amounts of supplemented copper or feeds that have been contaminated with copper compounds used for other agricultural or industrial purposes (Underwood, 1977). When dairy cattle consume excessive copper, they may extremely accumulate large amounts of the mineral in the liver before toxicity becomes evident (NRC, 2001). Lead and cadmium are rarely found in excessive levels in poultry litter and the toxicity of lead and cadmium depends greatly upon the chemical nature of the compound and its absorption by the body (Fontenot and Jurubescu, 1980).

The accumulation of minerals in animal wastes is therefore a relatively minor problem within the context of the potential health hazards of waste recycling. In formulating rations, it is however necessary to limit quantities of animal waste so that the content of critical mineral contamination does not exceed tolerance levels (Gibbons et al., 1970).

Cadmium is a toxic element that accumulates within the body particularly in kidneys causing renal damage. The maximal tolerable cadmium concentration in the diet of cattle was set at $0.5 \mathrm{mg} / \mathrm{kg}$ in an effort to avoid adding cadmium to the diet of humans consuming animal's products (NRC, 2001).

Lead is the most common cause of toxicty in domestic livestock. Lead accumulates in the kidney cortex and renal tubular inclusion bodies suggest impaired renal function (Neathery and Miller, 1975).

Friesian calves fed broiler litter suffered pronounced necrobiotic changes associated with hydropic degeneration of liver and hepatic lesions (Salama, 1995). The same author indicated that the hepatocytes appeared enlarged and vaculated with presence of small to large intracytoplasmic eosenophilic spheroidal inclusions.

The objectives of this study were to investigate the effects of feeding different levels of poultry litter and corn silage on some heavy metals accumulation and histological aspects of body tissues of growing Friesian calves.

\section{MATERIALS AND METHODS}

The current work was carried out at Karada Animal Production Research Station, Animal Production Research Institute, Agricultural Research Center, Ministry of Agriculture. Eighteen male Friesian calves with an average body weight of $187 \pm$ $2.50 \mathrm{~kg}$ and $9 \pm 0.19$ months of age were divided into three similar groups ( 6 in each) according to their live body weight and age. The three groups were assigned at random to receive one of the three experimental diets. The feeding trial lasted 8 months and calves were individually fed the experimental rations containing different levels of poultry litter and corn silage to cover the requirements of growing calves according to NRC (1996) as shown in Table (1). 
Table 1. Formulation of the experimental rations and dry matter intake by growing Friesian calves

\begin{tabular}{lccc}
\hline \multirow{2}{*}{ Items } & \multicolumn{3}{c}{ Experimental rations } \\
\cline { 2 - 4 } & R1 (control) & R2 & R3 \\
\hline Ration formulation \% on DM basis & & & \\
Concentrate feed mixture & 65.0 & - & - \\
Berseem hay & 15.0 & - & - \\
Corn silage & - & 75.0 & 50.0 \\
Corn grains & - & 12.5 & 25.0 \\
Poultry litter & - & 12.5 & 25.0 \\
Rice straw & 20.0 & - & - \\
DM intake (kg / day) & 9.40 & 9.15 & 9.28 \\
\hline
\end{tabular}

The control ration is the ration used by most producers. Concentrate feed mixture is consisted of $32 \%$ undecorticated cotton seed cake, 5\% linseed cake, $22 \%$ yellow corn, $26 \%$ wheat bran, $12 \%$ rice bran, $2 \%$ molasses, $0.5 \%$ limestone and $0.5 \%$ common salt. Concentrate feed mixture or poultry litter and corn grain mixture were offered two times daily at $08.00 \mathrm{~h}$ and $16.00 \mathrm{~h}$, while rice straw was given two times daily at $12.00 \mathrm{~h}$ and $17.00 \mathrm{~h}$; berseem hay and corn silage were given once daily at $10.00 \mathrm{~h}$. Drinking water was offered ad lib 3 times a day.

Blood samples were collected once a month from the jugular vein of all calves by sterile needle into a dry clean plastic tube containing heparin as an anticoagulant. Samples were centrifuged at $4000 \mathrm{rpm}$ for 15 minute to obtain plasma. Two successive semen ejaculates were weekly collected from each calf in an interval of 30 minutes using artificial vagina. Semen was centrifuged at $3000 \mathrm{rpm}$ for 15 minute to obtain seminal plasma. At the end of the experiment after 8 months (when average body weight of each group was $450 \mathrm{~kg}$ ), three calves from each group were chosen randomly, weighed after fasting for 16 hours and slaughtered. Upon completion of bleeding, animals were skinned, dressed out and samples of muscle, liver, kidneys and testes were taken for chemical analysis.

The samples of feedstuffs, blood and seminal plasma, muscles, liver, kidneys and testes were prepared for copper, cadmium and lead determination according to the methods of A.O.A.C. (1990). The concentrations of these elements were determined by Atomic Absorption Spectrophotometer (Perkin Elmer 2380).

For histological studies, tissue samples from liver, kidneys and testes were taken just after slaughtering and fixed in 10\% formalin solution. After proper fixation the samples were dehydrated, cleared and embedded in paraffin wax. Sections of 5-7 microns thick were obtained and stained with Haematoxylin and Eosin stain. All stain techniques were carried out according to Bancroft and Stevens (1990).

The data obtained for these elements determinations were statistically analyzed using general linear model procedure adopted by SPSS (1999) for user's guide as one-way ANOVA. Also, Duncan's test within program of SPSS was done to determine the degree of significance between the means. 


\section{RESULTS AND DISCUSSION}

The contents of copper $(\mathrm{Cu})$, cadmium $(\mathrm{Cd})$ and lead $(\mathrm{Pb})$ of poultry litter were higher compared with the other tested feedstuffs. Therefore, the calculated $\mathrm{Cu}, \mathrm{Cd}$ and $\mathrm{Pb}$ contents of the experimental rations containing poultry litter and corn silage were higher than in the control ration and increased with increasing the level of poultry litter and decreasing the level of corn silage (R2 and R3) (Table 2). Moreover, data in Table (2) revealed that the intake from $\mathrm{Cu}, \mathrm{Cd}$ and $\mathrm{Pb}$ increased $(\mathrm{P}<0.05)$ with increasing the level of poultry litter and decreasing the level of corn silage in the experimental rations. Increased $\mathrm{Cu}, \mathrm{Cd}$ and $\mathrm{Pb}$ contents in the two experimental rations (R2 \& R3) as well as the intake of these elements by the calves could be attributed to the excessive levels of $\mathrm{Cu}, \mathrm{Cd}$ and $\mathrm{Pb}$ in tested poultry litter (Table 2). These results agree with those obtained by El-Amary (1995) and Salama (1995) who indicated that $\mathrm{Cu}, \mathrm{Cd}$ and $\mathrm{Pb}$ intake increased with increasing the proportion of poultry litter in the ration.

Table 2. Heavy metals contents of tested feedstuffs and experimental rations and intake by the studied Friesian calves

\begin{tabular}{lccc}
\hline Items & Copper $(\mathbf{C u})$ & Cadmium $(\mathbf{C d})$ & Lead $(\mathbf{P b})$ \\
\cline { 2 - 4 } Contents & \multicolumn{3}{c}{ (mg / kg DM basis) } \\
\hline Feedstuffs & & & \\
Concentrate feed mixture & 11.70 & 0.130 & 4.45 \\
Berseem hay & 10.15 & 0.115 & 3.94 \\
Corn silage & 9.80 & 0.135 & 4.62 \\
Corn grains & 4.35 & 0.125 & 3.65 \\
Poultry litter & 45.50 & 0.420 & 25.38 \\
Rice straw & 4.95 & 0.140 & 4.79 \\
Experimental rations & & & \\
R1 (control) & 10.12 & 0.130 & 4.44 \\
R2 & 13.58 & 0.169 & 7.09 \\
R3 & 17.36 & 0.204 & 9.57 \\
Intake & & $\mathbf{m g} / \mathbf{d a y}$ & \\
R1 (control) & $97.01^{\mathrm{c}}$ & $1.22^{\mathrm{c}}$ & $41.74^{\mathrm{c}}$ \\
R2 & $124.26^{\mathrm{b}}$ & $1.55^{\mathrm{b}}$ & $64.87^{\mathrm{b}}$ \\
R3 & $161.10^{\mathrm{a}}$ & $1.89^{\mathrm{a}}$ & $88.81^{\mathrm{a}}$ \\
MSE & 4.08 & 0.06 & 2.06 \\
\hline
\end{tabular}

$\mathrm{a}, \mathrm{b}$ and $\mathrm{c}$ : Means in the same column with different superscripts differ significantly $(\mathrm{P}<0.05)$.

The concentrations of $\mathrm{Cu}, \mathrm{Cd}$ and $\mathrm{Pb}$ in blood plasma as well as in seminal plasma of Friesian calves increased $(\mathrm{P}<0.05)$ with increasing the level of poultry litter in the rations (Table 3). The increased concentrations of $\mathrm{Cu}, \mathrm{Cd}$ and $\mathrm{Pb}$ in blood and seminal plasma is due to the increased $\mathrm{Cu}, \mathrm{Cd}$ and $\mathrm{Pb}$ contents of experimental rations and subsequently the intake (Table 2). The concentrations of $\mathrm{Cu}, \mathrm{Cd}$ and $\mathrm{Pb}$ in blood and seminal plasma for calves fed R3 (containing 25\% poultry litter) were higher than the normal levels as previously reported by Georgievskii et al. (1982). Moreover, the concentrations of $\mathrm{Cu}, \mathrm{Cd}$ and $\mathrm{Pb}$ in blood plasma were higher than in 
seminal plasma. Significant correlations existed between the quantities of $\mathrm{Cu}, \mathrm{Cd}$ and $\mathrm{Pb}$ intake and concentrations in blood plasma with coefficients of $0.35,0.52$ and 0.47 , respectively $(\mathrm{P}<0.05)$. The corresponding correlations for seminal plasma were $0.28,0.45$ and 0.37 , respectively $(\mathrm{P}<0.05)$. The high positive correlations between the concentrations of $\mathrm{Cu}, \mathrm{Cd}$ and $\mathrm{Pb}$ in blood and seminal plasma reached $0.85,0.73$ and 0.75 coefficients, respectively $(\mathrm{P}<0.05)$. These results are in accordance with those obtained by El-Amary (1995) who found that $\mathrm{Cu}, \mathrm{Cd}$ and $\mathrm{Pb}$ concentrations in blood serum increased with increasing the level of poultry litter in the ration. Moreover, $\mathrm{Xu}$ et al. (1993) reported that the concentrations of $\mathrm{Cu}, \mathrm{Cd}$ and $\mathrm{Pb}$ were generally higher in blood than in seminal plasma.

Table 3. Heavy metals concentrations in blood and seminal plasma of Friesian calves fed the experimental rations

\begin{tabular}{lcccc}
\hline \multirow{2}{*}{ Items } & \multicolumn{4}{c}{ Experimental rations } \\
\cline { 2 - 5 } & \multicolumn{5}{c}{$\mathbf{R 2}$} & $\mathbf{R 3}$ & MSE \\
\hline Blood plasma & \multicolumn{4}{c}{$\mathbf{( u g} / \mathbf{1 0 0} \mathbf{~ m l})$} \\
Copper $(\mathrm{Cu})$ & $105.35^{\mathrm{c}}$ & $118.75^{\mathrm{b}}$ & $138.60^{\mathrm{a}}$ & 3.29 \\
Cadmium $(\mathrm{Cd})$ & $5.25^{\mathrm{c}}$ & $7.15^{\mathrm{b}}$ & $10.45^{\mathrm{a}}$ & 0.50 \\
Lead $(\mathrm{Pb})$ & $12.25^{\mathrm{c}}$ & $14.85^{\mathrm{b}}$ & $17.90^{\mathrm{a}}$ & 4.24 \\
Seminal plasma & & & & \\
Copper $(\mathrm{Cu})$ & $90.30^{\mathrm{c}}$ & $104.25^{\mathrm{b}}$ & $130.80^{\mathrm{a}}$ & 4.03 \\
Cadmium $(\mathrm{Cd})$ & $5.49^{\mathrm{c}}$ & $6.24^{\mathrm{b}}$ & $7.98^{\mathrm{a}}$ & 0.01 \\
Lead $(\mathrm{Pb})$ & $12.95^{\mathrm{c}}$ & $14.55^{\mathrm{b}}$ & $17.80^{\mathrm{a}}$ & 0.70 \\
\hline
\end{tabular}

$\mathrm{a}, \mathrm{b}$ and $\mathrm{c}$ : Means in the same row with different superscripts differ significantly $(\mathrm{P}<0.05)$.

Calves fed $\mathrm{R} 2$ and $\mathrm{R} 3$ accumulated more $\mathrm{Cu}, \mathrm{Cd}$ and $\mathrm{Pb}$ in body tissues compared with the R1 group (control). This result is expectedly due to the high concentration of these three elements in the experimental rations and subsequently the intake (Table 2 ). The results presented in Table (4) revealed that the concentrations of $\mathrm{Cu}, \mathrm{Cd}$ and $\mathrm{Pb}$ in muscles, liver, kidneys and testes of Friesian calves significantly $(\mathrm{P}<0.05)$ increased with increasing the level of poultry litter and decreasing the level of corn silage in the rations. The increases of $\mathrm{Cu}, \mathrm{Cd}$ and $\mathrm{Pb}$ accumulation in body tissues with increasing the level of poultry litter in the rations is due to increasing $\mathrm{Cu}, \mathrm{Cd}$ and $\mathrm{Pb}$ contents in the experimental ration and intake with increasing the level of poultry litter in the ration (Table 2). The highest accumulation of $\mathrm{Cu}$ and $\mathrm{Pb}$ were found in liver followed by kidneys, while the highest accumulation of $\mathrm{Cd}$ was found in kidneys followed by liver. However, muscle and testis showed the lowest accumulation of these elements. 
Table 4. Heavy metals contents in body tissues of Friesian calves fed experimental rations

\begin{tabular}{lcccc}
\hline \multirow{2}{*}{ Items } & \multicolumn{4}{c}{ Experimental rations } \\
\cline { 2 - 5 } Liver & $\mathbf{R 1}$ & $\mathbf{R 2}$ & $\mathbf{R 3}$ & MSE \\
\hline Copper $(\mathrm{Cu})$ & & $\mathbf{m g} / \mathbf{~ k g ~ D M ~ b a s i s )}$ & \\
Cadmium $(\mathrm{Cd})$ & $30.35^{\mathrm{c}}$ & $39.65^{\mathrm{b}}$ & $55.70^{\mathrm{a}}$ & 7.89 \\
Lead $(\mathrm{Pb})$ & $1.52^{\mathrm{c}}$ & $1.85^{\mathrm{b}}$ & $2.35^{\mathrm{a}}$ & 0.08 \\
Kidneys & $0.50^{\mathrm{c}}$ & $0.65^{\mathrm{b}}$ & $0.90^{\mathrm{a}}$ & 0.04 \\
Copper $(\mathrm{Cu})$ & & & & \\
Cadmium $(\mathrm{Cd})$ & $5.45^{\mathrm{c}}$ & $7.65^{\mathrm{b}}$ & $9.30^{\mathrm{a}}$ & 0.92 \\
Lead $(\mathrm{Pb})$ & $15.50^{\mathrm{c}}$ & $19.85^{\mathrm{b}}$ & $25.25^{\mathrm{a}}$ & 0.97 \\
Testis & $0.35^{\mathrm{c}}$ & $0.52^{\mathrm{b}}$ & $0.85^{\mathrm{a}}$ & 0.05 \\
Copper $(\mathrm{Cu})$ & & & & \\
Cadmium $(\mathrm{Cd})$ & $6.30^{\mathrm{c}}$ & $7.25^{\mathrm{b}}$ & $8.60^{\mathrm{a}}$ & 0.23 \\
Lead $(\mathrm{Pb})$ & $3.20^{\mathrm{c}}$ & $4.75^{\mathrm{b}}$ & $6.10^{\mathrm{a}}$ & 0.29 \\
Muscle & $0.20^{\mathrm{c}}$ & $0.28^{\mathrm{b}}$ & $0.42^{\mathrm{a}}$ & 0.02 \\
Copper $(\mathrm{Cu})$ & & & & \\
Cadmium $(\mathrm{Cd})$ & $8.35^{\mathrm{c}}$ & $8.95^{\mathrm{b}}$ & $9.60^{\mathrm{a}}$ & 0.60 \\
Lead $(\mathrm{Pb})$ & $6.35^{\mathrm{c}}$ & $7.95^{\mathrm{b}}$ & $9.80^{\mathrm{a}}$ & 0.34 \\
\hline
\end{tabular}

$\mathrm{a}, \mathrm{b}$ and $\mathrm{c}$ : Means in the same row with different superscripts differ significantly $(\mathrm{P}<0.05)$.

The significant correlation coefficients $(\mathrm{P}<0.05)$ between the intake of $\mathrm{Cu}, \mathrm{Cd}$ and $\mathrm{Pb}$ and their concentrations were $0.70,0.53$ and 0.74 in liver; $0.58,0.76$ and 0.65 in kidneys; $0.35,0.25$ and 0.30 in muscle and $0.32,0.42$ and 0.36 in testis, respectively.

The contents of $\mathrm{Cu}, \mathrm{Cd}$ and $\mathrm{Pb}$ in body tissues of calves fed $\mathrm{R} 3$ (containing $25 \%$ poultry litter) were higher than the normal levels as suggested by McDowell (1992). Additionally, Salama (1995) found that the concentrations of $\mathrm{Cu}, \mathrm{Cd}$ and $\mathrm{Pb}$ in muscle, liver and kidneys increased with increasing the level of poultry litter in the rations. Lopez Alonso et al. (2000 \& 2003) reported that increasing $\mathrm{Cu}, \mathrm{Cd}$ and $\mathrm{Pb}$ intake led to increasing the accumulation of $\mathrm{Cu}, \mathrm{Cd}$ and $\mathrm{Pb}$ in liver, kidneys, muscle and testes. The higher content of $\mathrm{Cu}$ in the liver of calves is strongly dependent on its concentration in the diet (Georgievskii et al., 1982). Results concerning the higher accumulation of heavy metals in liver and kidneys than in muscle are in agreement with by Bellof et al. (2000).

\section{Histological aspects:}

Friesian calves fed R1 (control ration) and R2 (12.5\% poultry litter) showed normal polygonal hepatocyte containing PAs + ve granules (Fig. 1). However, calves fed R3 (25\% poultry litter) showed that some hepatocytes lost their architectur (Fig. 2 ). Their nuclei appeared more pyknotic. Severely damaged hepatocytes, which lost their histological pattern, were observed in different areas in the liver. The centrolobular hepatocytes became more vacuolated, enlarged, and the PAs + ve granules were reduced in the cytoplasm of some cells. Lymphocytic infiltration was 
found between hepatocytes and these necrotic areas (Fig. 3). These results are due to increasing the intake of $\mathrm{Cu}, \mathrm{Cd}$ and $\mathrm{Pb}$ with increasing the level of poultry litter in the ration. These results agree with those obtained by Canton-Castillo et al. (1994) who showed that liver and kidneys of sheep given diets containing poultry litter were damaged in all treated groups. Also, Salama (1995) reported that liver of animals fed poultry litter enhanced hepatic degeneration.

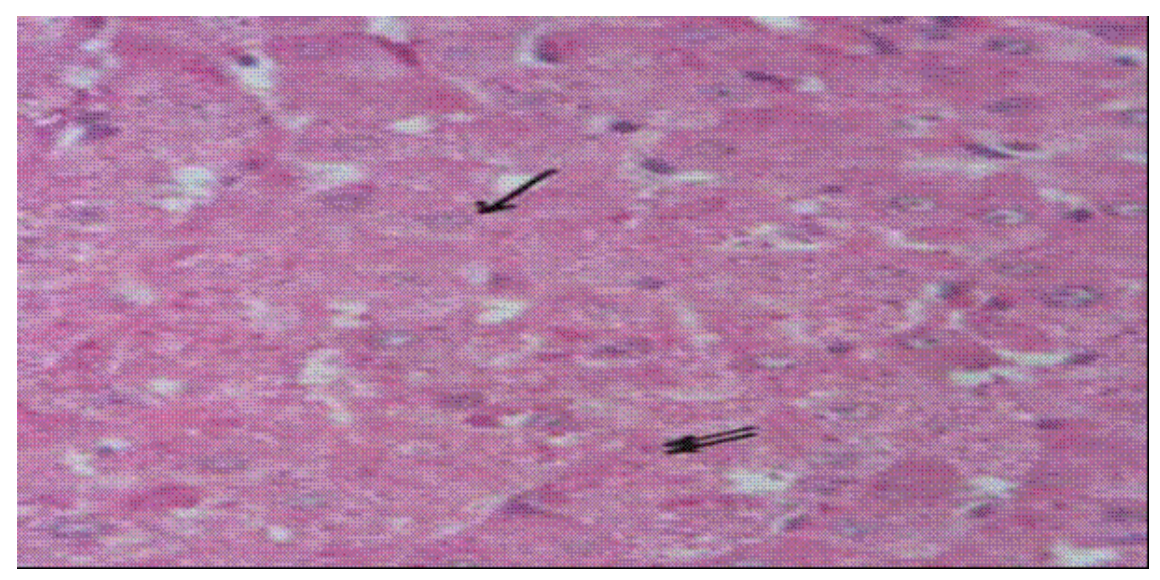

Fig. 1. Paraffin section in liver of calves fed R1 showing normal polygonal hepatocytes (arrow) and few PAs + ve granules (two arrows). (PAs Tech. x: 400)

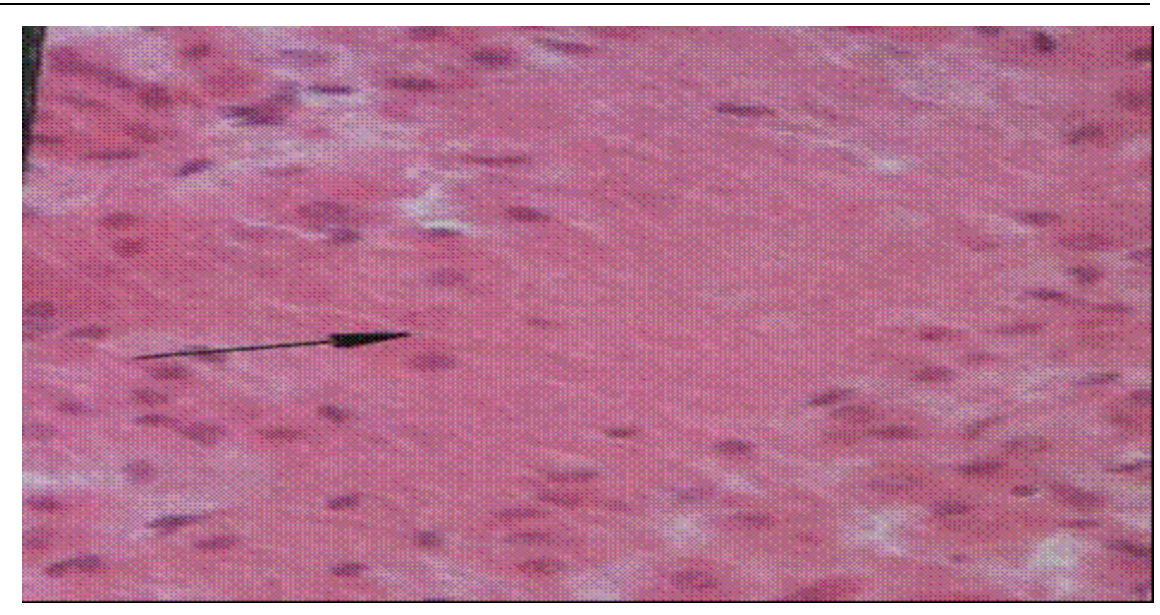

Fig. 2. Paraffin section in liver of calves fed R2 showing severely damaged 


\section{hepatocytes (arrow). (H \& E stain, $x: 400)$}

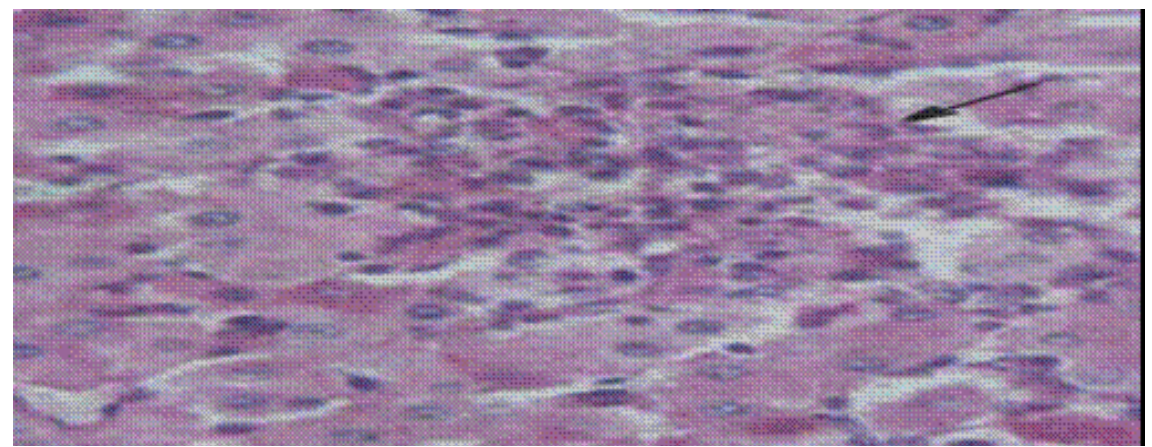

Fig. 3. Paraffin section in liver of calves fed $R 3$ showing lymphocytic infiltration between hepatocytes (arrow). ((PAs Tech. $x$ : 400)

Friesian calves fed R1 and R2 showed the normal convoluted tubules of kidneys (Fig. 4). In calves fed R3 the lining epithelium surrounding the lumen of the convoluted tubules was more dilated with some destructed cells while the interstitial tissue was infiltrated by lymphocytes (Fig. 5). Also, the glomeruli lost their architecture as hypercellularity, increasing the amount of mesengial matrix, which appeared as a PAs + ve stained areas in the glomeroli, the nuclei of mesengial cells and podocytes were deeply stained and showed pyknosis (Fig. 6). These results are produced by the increased intake of $\mathrm{Cu}, \mathrm{Cd}$ and $\mathrm{Pb}$ with increasing the level of poultry litter in the ration. These results are in agreement with those obtained by Canton-Castillo et al. (1994) who found that liver and kidneys of sheep given diets containing poultry litter was damaged in all treated groups. Also, Salama (1995) found that kidneys of Friesian calves fed ration containing 30\% poultry litter suffered from microbiotic changes associated with lobular dilation, while the epithilial lining of the tubules appeared vacuolated with pyknotic nuclei. 


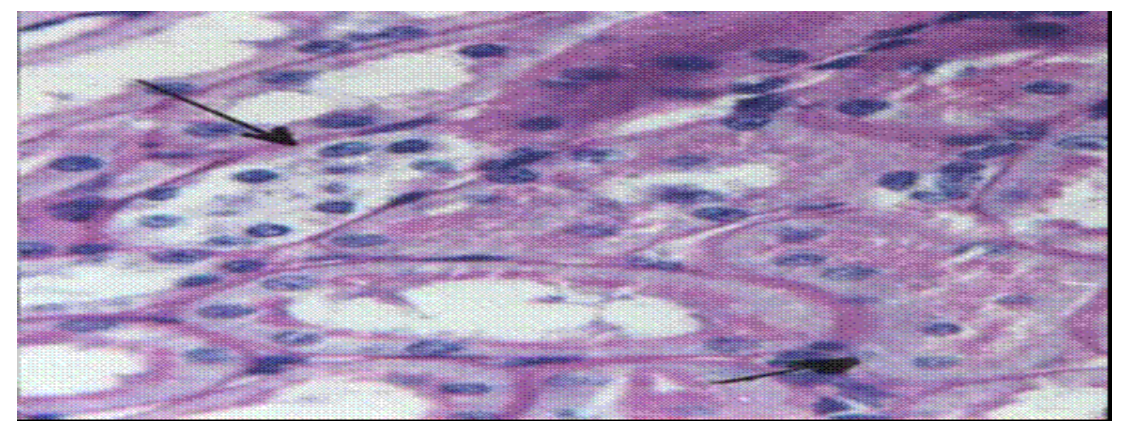

Fig. 4. Paraffin section in kidneys of calves fed R1 showing normal convoluted tubules (arrow). (PAs Tech. x: 400)

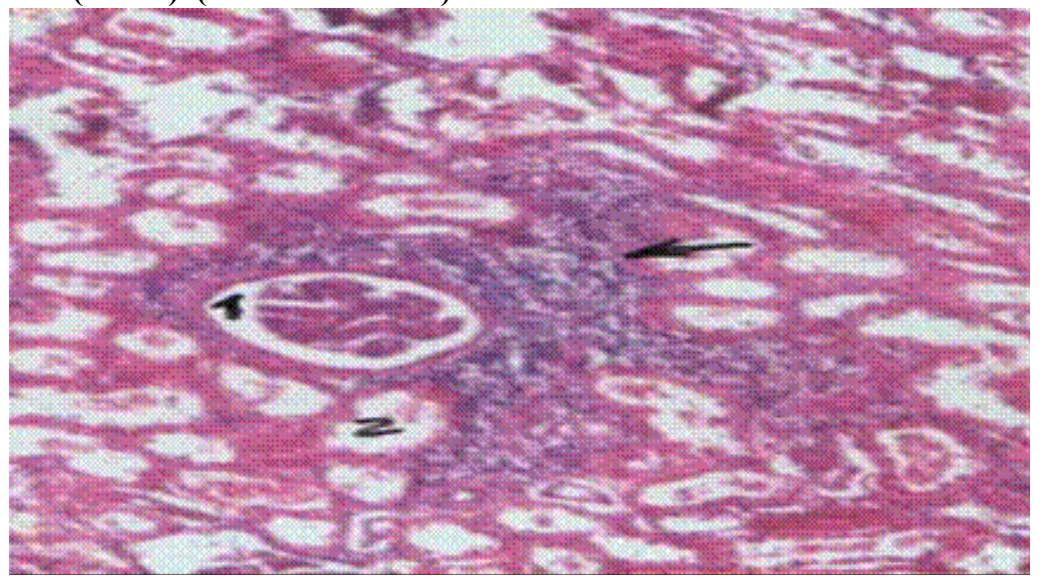

Fig. 5. Paraffin section in kidneys of calves fed R2 showing the glomeruli (1), lumen of convoluted tubule (2) and lymphocytic infiltration (arrow). (PAs Tech. $x:$ 400) 


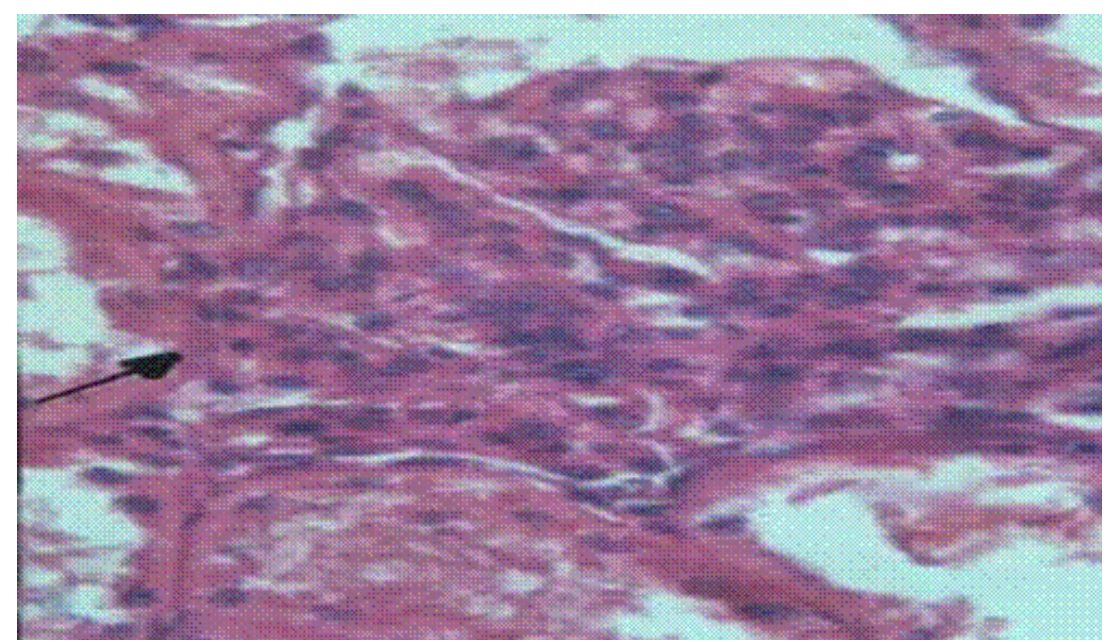

Fig. 6. Paraffin section in kidneys of calves fed R3 showing the glomeruli lost their architecture (arrow). (PAs Tech. $x:$ 400)

The seminiferous tubules in testis of Friesian male calves fed R1 and R2 were healthy and revealed different stages of spermatogenesis reaching the elongated spermatids (Fig. 7). On the contrary, some of the semineferous tubules of calves fed R3 showed signs of degeneration and necrosis (Fig. 8). These results are to increase the intake of $\mathrm{Cu}, \mathrm{Cd}$ and $\mathrm{Pb}$ with increasing the level of poultry litter in the ration.

It could be concluded that using poultry litter in the ration of growing calves at the level of $25 \%$ of DM basis led to an increase in the concentration of heavy metals in blood and seminal plasma and accumulation of these elements in body tissues causing abnormal histological structure. The results indicated that poultry litter should not exceed $12.5 \%$ on DM basis of the ration. 


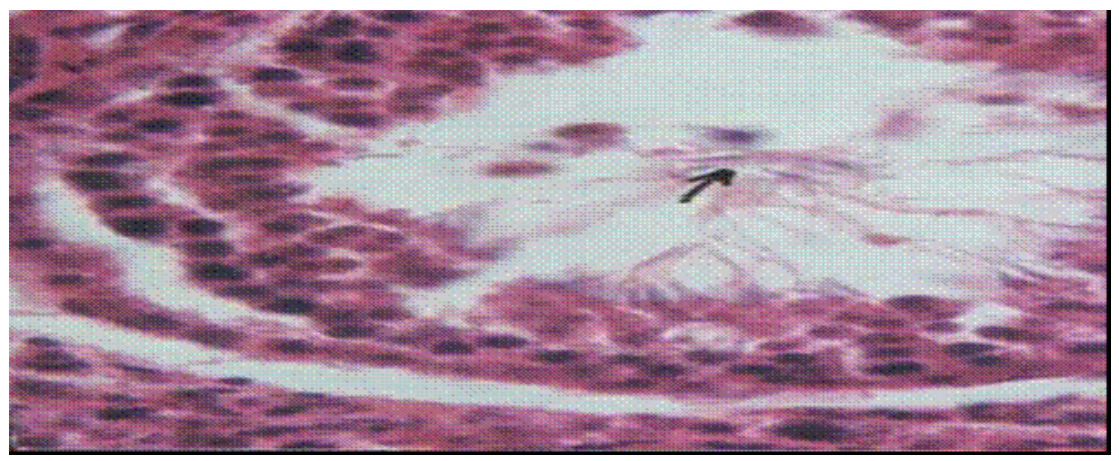

Fig. 7. Paraffin section in testis of calves fed R1 showing somniferous tubules (arrow), contain spermatogonia (1), Iry spermatocytes (2) and spermatid (3). (H \& E stain, $x$ : 100)

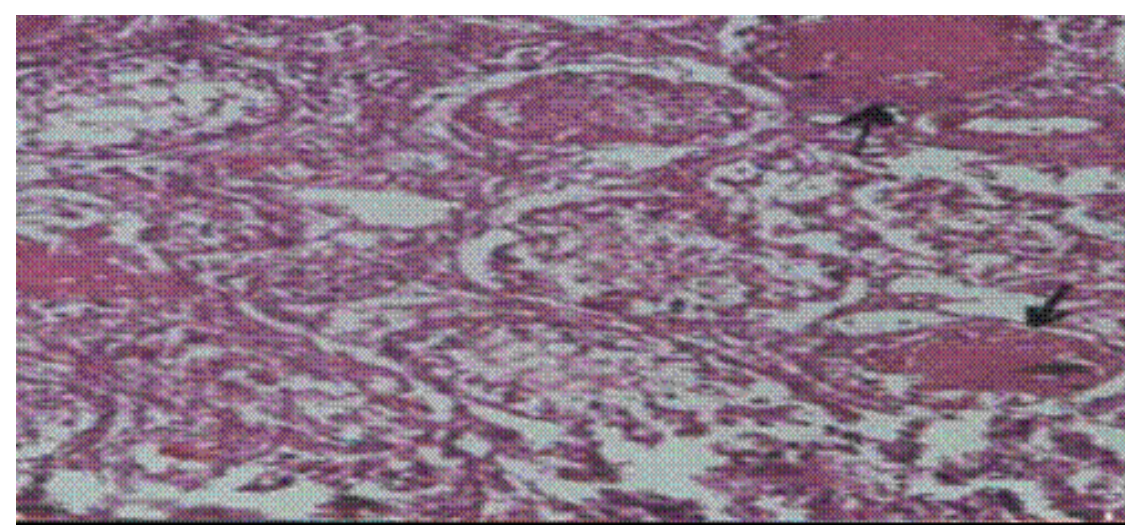

Fig. 8. Paraffin section in testis of calves fed $R 2$ and $R 3$ showing signs of degeneration and necrosis of somniferous tubules. (arrow). (PAs Tech. x: 100)

\section{REFERENCES}

A.O.A.C., 1990. Association of Official Analytical Chemists. Official Methods of Analysis, $15^{\text {th }}$ Ed., Washington, D. C.

Bancroft, J. D. and A. Steven, 1990. Theory and Practice of Histological Techniques. Churchill Livingtsone, Edinberg, London.

Bellof, G.; A. Wolf; H. O. Knoppler and H. Tenhumberg, 2000. Intake of heavy metals (lead, cadmium, zinc) originating from colored paints and their 
incorporation into organs and tissues of heifers. Dtsch. Tierarztl Wochenschr, 107: 455.

Canton-Castillo, J. G.; Y. Moguel-Ordonez; O. Rojas-Rodriguez; E. Sauri-Duch; J. Miranda-Soberanis and A. F. Castellanos-Ruelas, 1994. Estimation of damage induced by copper in poultry litter used in feeding sheep. Techica-pecuaria-enMexico, 32(2): 82-89.

El-Amary, Hanaa H., 1995. The relation between the utilization of treated poultry litter wastes as feed ingredient and accumulation of heavy metals in animal tissues. Ph. D. Thesis, Fac. of Agric., Ain Shams Univ.

Fontenot, J. P. and V. Jurubescu, 1980. Processing of animal waste by feeding to ruminants. In "Digestive Physiology and Metabolism in Ruminants". Y. Ruchebusch \& P. Thivend, Eds., AVI Publishing Co. USA.

Georgievskii, V. I.; B. N. Annenkov and V. T. Samokhin, 1982. Mineral Nutrition of Animal. $1^{\text {st }}$ published in English. Butterworth \& Co. Publishers, Ltd, London, England.

Gibbons, W. J., E. J. Catcolt and J. F. Smith Cors, 1970. Borine medicine and surgery. Amer. Vet. Publ., INC.

Lopez Alonso, M., F. Prieto Montana, M. Miranda; C. Castillo, J. Hernandez and J. L. Benedito, 2003. Heavy metals accumulation in cattle in NW Spain. Vet. Hum. Toxicol., 45: 128.

Lopez Alonso, M., J. L. Benedito, M. Miranda, C. Castillo, J. Hernandez and R. F. Shore, 2000. Toxic and trace elements in liver, kidneys and meat from cattle slaughtered in Galicia (NW Spain). Food Addit. Contam., 17: 447.

McDowell, L. R., 1992. Minerals in Animal and Human Nutrition. $3^{\text {rd }}$ Ed. Academic Press, Washington, DC.

Neathery, M.W. and W.J. Miller, 1975. Metabolism and toxicity of cadmium, mercury and lead in animals: A review, J. Dairy Sci., 58: 1767.

NRC, 1996. Nutrient Requirements of Beef Cattle. $7^{\text {th }}$ ed., National Academy Press, Washington, D. C.

NRC, 2001. Nutrient Requirements of Dairy Cattle. $7^{\text {th }}$ Ed., National Acadimic Press. Washington, D. C.

Salama, A.M.A., 1995. Studies on some nutritional factors affecting meat production from cattle. M.Sc. Thesis, Fac. of Agric., Ain Shams Univ., Egypt.

SPSS, 1999. Statistical package for the social sciences, Release 10, SPSS INC, Chicago, USA.

Underwood, E.J., 1977. Trace elements in Human and Animal Nutrition. $4^{\text {th }}$ ed., Academic Press, New York.

Westing, T.W., J. P. Fontenot, W. H. McClure, R. F. Kelly and K. E. Webb, Jr, 1985. Characterization of mineral elements profile in animal waste and tissues from cattle fed animal waste. 1- Heifers fed broiler litter. J. Anim. Sci., 61: 670.

Xu, B., S. E. Chia, M. Tsakok and C. N. Ong, 1993. Trace elements in blood and seminal plasma and their relationship to sperm quality. Reprod. Toxicol., 7: 613. 
تراكم بعض العناصر الثقيلة والمظاهر الهستولوجية لأنسجة الجسم فى العجول الفريزيان

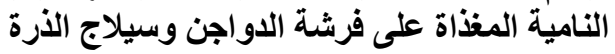

الفتاح علىمد عبد المجيد جعفر'، رجب محمد أبوعيانة،، جمـال حسنى عبد الله غـانم، منى عبد

1- معهة بحوث الإتتاج الحيوانى، مركز البحوث الزراعية، الدقى، الجيزة، 2- كلية الطب البيطرى بكفرالثيخ، جامعة طنطا

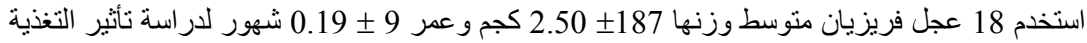

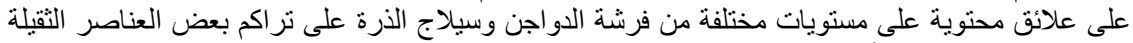

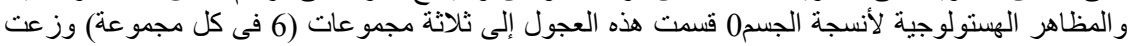
عشو ائيا على العلائق التالية:-

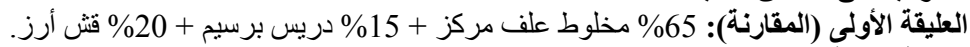

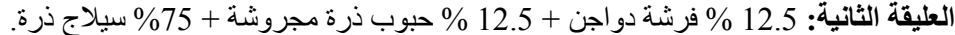

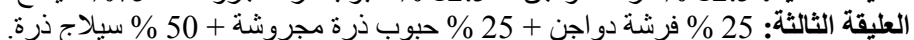

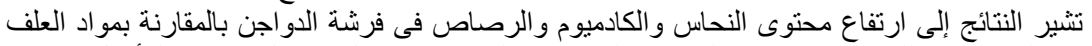

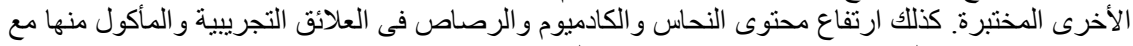

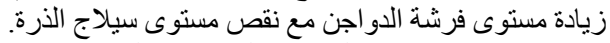

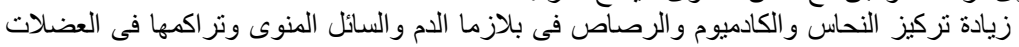

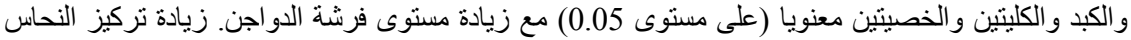

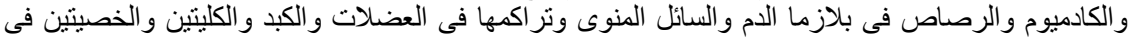

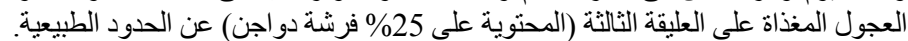

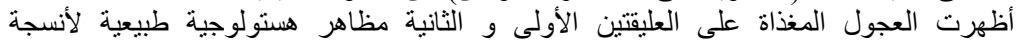

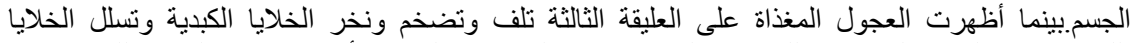

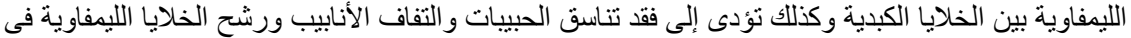

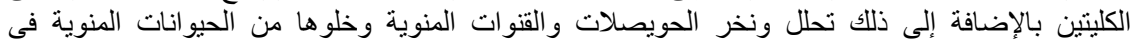

نستخلص من هذه الدراسة أن استخدام فرشة الدواجن بمستوى 25\% على أسلى أساس المادة الجافة فى علائق

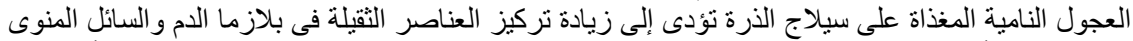

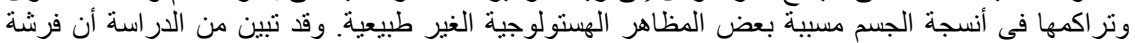
الدو اجن يجب ألا تزيد عن 12.5\% في عليقة العجول الفريزيان النامية على أساس المادة الجافية. 